\title{
Maintenance of Lampung Language in Padang Cermin District
}

Citra Wulandari

citrauhlx@gmail.com

\author{
Universitas Teknokrat Indonesia
}

\begin{abstract}
The aim of this study is to know how far the maintenance and the shift of Lampung language in Padang Cermin district are. Most of Padang Cermin society uses their mother tongue which is Lampung language while their second language is Indonesia Language. Most of them establish the kinship or directly interact with Lampung ethnic so that they can speak Lampung language. A qualitative method was applied in this study and involves 30 respondents from five villages in Padang Cermin district which are Tanjung Mas, Paya, Sanggi, Pal Satu, and Durian based on gender, ages, marriage status, education, occupation and place of birth by observing, interviewing and giving questionnaire. The result shows that there are still many of them uses the dominant language which is Lampung language and the language attitudes towards them tend to be positive. It also found that the language shift occurs from several factors; education development, social, government, behavior, and economic development.
\end{abstract}

Key Words: Language attitude, language maintenance, language shift, Padang Cermin

\section{Introduction}

Language is a dominant communication tool for humans to communicate between two or more human beings. Based on region of use, language is distinguished into foreign languages, national languages and regional languages. Based on the state of use, language is differentiated into three, namely language maintenance, language shift and language death (Sumarsono, 2012: 231). Indonesia is a country which consists of thousands of islands with different tribes. The diversity makes Indonesia become the laboratory language. However, within the development, local language is increasingly marginalized. It is because of the parents' tendency who do not leave the regional language to their children due to some factors, such as the development of education, association, assimilation and others. As a result, it can cause the language shift which is marked by the language changes of minority groups into languages majority group. Group which has more dominant language reluctant to adopt the language of minority groups (Holmes, 2001: 56). If there is no revitalization action, this fact may lead to language death. Even though, Crystal states that language death is a tragedy because when every single language is dead, the world lost philosophers, anthropologists, storytellers, psychologists, linguists, and author (Crystal, 2000: 53). Language maintenance and language shift is closely related to the human behavior, is closely related to change both psychological and socio-cultural, especially in the bilingual and multilingual community. In the bilingual and multilingual community, language contact mostly occurs so that there will be language competition among them. Language contact can occur because there is immigration, cultural relations which is close also education (Mesthrie, et al., 2000).

One of the local languages in Indonesia is Lampung language. The word Lampung comes from the word "Anjak Lampung" which means comes from height. This is because Lampung Puyang nation first settled in the plateau of Sekak Brak in the slope of Mount Pesagi. Lampung language based on the classification formulated by Van Royen is divided into two dialects namely dialect A and dialect O. Lampung ethnic community based on the division consists of the Saibatin community and Papadun which is divided into several regions. Papadun community lives in inland area that consists of Abung Siwo Mego (Unyai, Unyi, Subing, Uban, Anak Tuba, Kunang, Belinyuk, Selagai, Nyerupa. Masyarakat Abung mendiami 7 wilayah adat: Kotabumi, Seputih Timur, Sukada, Labuhan Maringgai, Jabung, Gunung Sugih, and Terbanggi while Saibatin is often called as Coastal Lampung because most of them are domiciled along east, south, and west coast of Lampung consisting of Paksi Pak Sekala Brak (Lampung Barat) - Bandar Lima Way Lima (Pesawaran) - Marga Lima Way Lima ( Lampung Timur) Keratuan Melinting (Lampung Timur) - Keratuan Darah Putih (Lampung Selatan) - Keratuan Komering (provinsi Sumatera Selatan). Still in the same references source, Dr. Van Royen classifies the clump of Lampung language into Subdialect, namely the Belalau Dialect, or Api Dialect and Abung or Nyow Dialect. 
Related to contact and language competition, Padang Cermin region is also an area with bilingual society. Most of Padang Cermin society uses their mother tongue which is Lampung language while their second language is Indonesia language. Most of them establish the kinship or directly interact with Lampung ethnic so that they can speak Lampung language. Bahasa Indonesia (BI) as the language of instruction dominates all aspects of life, such as politics, economic, educational, social, and culture. As a result, the role of Indonesian language indirectly replaces the role of regional languages in the public sphere. Some of the case of language shift in Padang Cermin area is firstly because there are many immigrants who live in this area, moreover in Padang Cermin there is a Marines area that has majority outside Lampung such as people from Java, Palembang, Kalimantan and any other regions. Most of them only speak Lampung language if they talk with the Lampungnese while Bahasa is for those who cannot speak Lampung language. According to Aitchison, environmental changes give a great influence on the language situation in a particular speech (Aitchison, 2001: 3-4). Some of old assumptions said the language changes run slowly so that it is difficult to observe. As a result, the occurrence of language change is often not realized.

From the explanation above, the aim of this study is to know how far the maintenance and the shift of Lampung language in Padang Cermin are. The next raises some research questions related to (1) the domains Lampung language is used by Padang Cermin society, (2) factors leading to Language maintenance and language shift, and (3) the attitude of Padang Cermin society towards Lampung language.

\section{Literary Review}

\section{Bilingualism}

Edwards (2008: 10) states that the concept of bilingualism refers to the level of someone's mastery over the second language inside the lowest level to that highest stage, which is mastering two languages that equally well. At a certain level, bilingualism can create multilingual or multilingual societies, referring to a person or group of people who speak two or more languages. Despite the many views of experts on the concept of bilingualism, they agree that both arise because of a meeting between one speech community and another speech community with different languages (contact language).

\section{Diglossia}

The concept of diglossia initially refers to the dialect and the variety of languages in one speech community (eka bahasa). Fishman (1967) then developed the notion of diglossia by referring to a language situation in which each language or variety of languages, whether in an ecumenical, bilingual, or multilingual society have different roles and functions. In other words, diglossia is a state in which society has two variations of language from one language used side by side. Each language has its own roles and functions. Furthermore, according to Fishman, the interaction between diglossia and bilingual forms four types of society: the society with bilingualism and diglossia, a society with digdossity without diglossia, a society with diglossia without bilinguality, a society without diglossia and without bilingualism. (Fishman, 1972: 91-106; Mestrhrie et al., 2000: 42).

\section{Domains}

The essence of the understanding of Diglossia is that there are two variations of language used separately in accordance with its function. One variation is used under certain conditions, while other variations are used under other conditions. This kind of condition is called the domains. Fishman (1972) argues that the domain is related to the condition in which an individual is required to choose a specific language and topic of conversation in accordance with the sociocultural norms of the speech culture concerned.

For example, when a mother talks with her child at the dinner table, the conversation that comes up is a relaxed conversation. The relationship is also a relationship of parents and children. This is called the family domain. However, when at school, if by chance the mother is a teacher of the child, then the variety of language used is the formal language. The relationship is also the relationship between teachers and students. This situation is called as the domain of education.

\section{Language Maintenance and Language Shift}

According Fasold (1984: 213-214) language maintenance is the result of the process of language selection in a very long period of time. Language maintenance is more about how a particular speech community maintains its mother tongue. Language maintenance also relates to an attitude problem or judgment of a language to be used 
in the midst of other languages. In a plural environment, speakers will tend to choose the language that is considered appropriate to understand the communication situation in where they live.

According to Fishman (1972), these communication activities depend on location, topic, and participants. (Fishman 1972, Hymes 1967). Surviving or not the language of a speech community led to the occurrence of language shift (language shift). Lieberson (1972) states that almost all cases of language shifting in society occur through intergenerational transitions in a bilingual society. However, there are also bilingual societies that can retain their language for centuries.

Fishman (1972) in his study states that language maintenance occurs not solely because of high loyalty or a strong sense of nationalism in a group. In rural communities, language maintenance tends to be high or not shifting due to other factors. In the case of language shifting, it does not mean that high prestige languages can replace languages with low prestige, whereas in terms of gender, the level of language shift, both in women and men can also be low or high due to certain factors. From the existing cases, Mesthrie quotes Giles et al. 1977; Appel and Muysken 1987: 32-45 summarize factors that cause language shifts, such as changes in economic conditions, status, demographics, and institutional support.

\section{Language Attitude}

The dynamics of language maintenance and language shift gave birth to the notion of language attitudes. Fishman (1972) says that the recognition of attitudes toward language is a very important topic for studying social behavior through language. Following the flow of Alport's thought cited by Suhardi (1996), attitudes are defined as "mental and nervous alert, structured through experiences that give dynamic direction or influence to a person's response to all objects and situations associated with that preparedness." Garvin and Mathiot, quoted by Chaer (2010) suggests some characteristics of language attitudes, namely language loyalty, language pride, and awareness of the norm.

First, language loyalty encourages the community to retain its language and prevent the influence of other languages. The lack of encouragement to maintain their language independence signifies that the speakers' loyalties are weak. It is categorized as a cognitive aspect, the aspect that humans use to think. Second, language pride encourages people to develop language and use it as a symbol of identity and community unity. This relates to the affective aspects associated with positive and negative attitudes, pleasant or unpleasant, proud or not proud. If a person diverts his or her pride to one language to another, it includes people who have negative language attitudes. For example, during the colonial period, precisely in the 1950s, many Indonesians are more proudly speaking Dutch than Indonesian because they are considered more prestigious. Third, the awareness of the norm that encourages people to use their language carefully and courteously; and is a very big factor influence on deed, that is activity use language (language use). In this section, explain connective or influential aspects of behavior. Thus, it can be concluded that language attitudes influence a person to use or choose a language. This study looks at whether or not people in the speech change the positive attitude or in other words be negative towards the language.

\section{Lampung Language in Padang Cermin}

Based on the population in Padang Cermin district, it obtains 65\% in which they are originally Lampung ethnic and the rest is dominated by ethnic of Javanese, and then uniformly ethnic Sundanese, Padang, Batak, etc.

There are two dominant language used in this district, Lampung Language and Indonesia Language. The majority in Padang Cermin district work as farmer, fisher, traders, teacher, entrepreneurs, government employees and marines. For those who can speak Lampung language only those who are originally Lampungnese. But when they meet the immigrants, they speak Indonesia language. Especially for those who worked as Marines, the majority of marine are immigrants. They come from different province to serve the country in Marines Area in Padang Cermin. Javanese has more population towards marines, that is Javanese language become the other language occurs in Padang Cermin after Lampung language and Indonesia language. Children in this area are taught Lampung language as their mother tongue by their parents since they were childhood, based on the interview it is done to keep their ancestral language for the next generation. Meanwhile interaction or contact with speakers in the coastal areas of Lampung, in which became the main route of inter-island trade, making the Lampung language used by the people of Padang Cermin affected by other languages.

The language of Lampung consists of two dialects, namely dialect $\mathrm{O}$ and dialect $\mathrm{A}$ (Van der Tuuk distinguishes Abung dialect and Pubian dialect; Dr. J.W. Van Royen distinguishes over the Api dialect and Nyou dialect). The dialect of $\mathrm{O}$ dialect includes Abung and Menggala. The languages of Lampung A include Waikanan, Sungkai, Melinting, Pubian, Coastal, and Jelema Daya. In learning Lampung language in school, dialect $\mathrm{O}$ and 
dialect $\mathrm{A}$ are taught side by side. This is one of the factors that caused the difficulties of the immigrant community to learn the language of Lampung.

Table 1. Example of sentences of the difference between $A$ dialect and $O$ dialect

\begin{tabular}{|l|l|l|l|}
\hline No. & \multicolumn{1}{|c|}{ A Dialect } & \multicolumn{1}{|c|}{ O Dialect } & \multicolumn{1}{c|}{ Indonesia Language } \\
\hline 1. & $\begin{array}{l}\text { Saya jeno tungga Pak Juned di } \\
\text { pasakh }\end{array}$ & $\begin{array}{l}\text { Nyak jenow tembuk Pak Juned } \\
\text { di pasagh }\end{array}$ & $\begin{array}{l}\text { Saya tadi bertemu dengan Pak } \\
\text { Juned di Pasar }\end{array}$ \\
\hline 2. & $\begin{array}{l}\text { Kapan niku mit haga liburan mit } \\
\text { lamban ne tamong? }\end{array}$ & $\begin{array}{l}\text { Kapan niku agow libugh adok } \\
\text { pok nenek? }\end{array}$ & $\begin{array}{l}\text { Kapan kamu mau berlibur ke } \\
\text { rumah nenek? }\end{array}$ \\
\hline 3. & Emak khadu masak makung? & Emak kak masak lak wak? & Ibu sudah masak belum? \\
\hline
\end{tabular}

\section{Method of Research}

This study uses a sociolinguistic approach, an approach that examines language in relation to society, or group behavior, not individuals (Wardhaugh and Fuller, 2015: 2). The method used in this research is a method that combines quantitative and qualitative approaches to see the tendency of language choice to be used and to explain the facts that actually occur in the field.

The study was conducted in five villages in Padang Cermin district. The location of the selected study is based on the consideration that the five points are the area of the village that still has a lot of indigenous people, but with the characteristics that more interact with heterogeneous (urban) communities.

This study involves 30 respondents from five villages which are Tanjung Mas, Paya, Sanggi, Pal Satu, and Durian based on gender, ages, marriage status, education, occupation and place of birth by observing, interviewing and questionnaire.

\section{Findings and Discussion}

\section{Pattern of Use and Language Choice}

This study on language maintenance and language shift is related to patterns of use and choice of community language in interacting. Fishman (1966), says that patterns of use and choice of language related to language domains, a kind of election behavior and the use of language in bilingual or multilingual societies linked to the social context or setting of speech, participants, topics, and communication functions.

In relation to the choice of language, respondents were asked to fill out questionnaires about which language they were using, to whom (family members, neighbors, friends, worker, etc.), on what topics (education, economics, politics, day-to-day, etc.) and in any domain (the domains of the home, the domains of the outdoors, the neighborhood, the religion domain, the domains of government, the domain of transactions, the domains of education, the domains of work), and the situations when getting upset, angry, or offended, and unconsciousness (dreaming, counting in the heart). From 30 respondents who fill the questionnaire, it is known that the most dominant language used is Indonesia Language

Tabel 2. Language use in daily life, based on the age of respondents

\begin{tabular}{|c|l|c|c|c|c|c|c|c|c|}
\hline No & Respondents' Age & Total & \% & LL* & \% & IL & \% & ML & \% \\
\hline 1 & $<20$ years old & 8 & 26 & 1 & 7,6 & 4 & 15,3 & 3 & 11,5 \\
\hline 2 & $20-40$ years old & 12 & 40 & 5 & 12,5 & 3 & 7,5 & 4 & 10 \\
\hline 3 & $>40$ years old & 10 & 34 & 6 & 17,6 & 2 & 5,8 & 2 & 5,8 \\
\hline & Total & 30 & 100 & 13 & & 8 & & 9 & \\
\hline & Percentage & & & & 43,3 & & 26,7 & & 30 \\
\hline
\end{tabular}

* IL = Indonesia Language, ML = Mixed Language (Lampung - Indonesia), LL = Lampung Language

The table above shows that from 30 respondents, $43,3 \%$ used Lampung Language as the most commonly used language, followed by Indonesia Language for $26,7 \%$ and also $30 \%$ for mixed language. The category of oldster respondents had the highest Lampung Language level of language maintenance compare to adult, teenagers and children which were 12,5\% and 7,6\%. Nevertheless, the use of Indonesia Language and Mixed-Language on the respondents who are above 40 years old in the table, the number is balanced, each of them had 2 people as much as $5,8 \%$. However, when the researcher interviewed the oldster respondents about what dominant language that they usually used in the domains of home, outdoor, neighborhood, religion, government, and education, they are more using Lampung Language as their dominant language compare to Indonesia Language and Mixed 
Language. Many of them used Indonesia Language when they talk to their children but not with their parents. The reason why they are proposing Lampung Language is that it is their mother tongue that they have since childhood, so that the language is sticky and enduring.

Same with the oldster respondents that adult respondent mostly used Lampung Language as their dominant language as much as $17,6 \%$. It is because the respondents that the writer interviewed are mostly a traders, so it is a possibility to use Lampung Language to interact with the Lampungnese or people who are not originally Lampungnese but able to speak Lampung Language. In balance, they also used Indonesia language $(5,8 \%)$ and Mixed Language $(5,8 \%)$ when in the domain of education, religion such as going to mosque meeting with new people and listening to the Ustadz's speech. Meanwhile the domain of transactions is a more plural domain, so most of the adult respondents use Indonesia Language mixed with Lampung Language.

Slightly different from adult respondents, the use of Indonesia Language in the children and adolescents respondents is very dominant as many as 4 people $(15,3 \%)$, compared with respondents of oldster $(7,5 \%)$ and adult $(5,8 \%)$. If it is detailed in all domains, the respondents of children and adolescents more dominantly use Indonesia Language in all domains. Even if a small number of people use Lampung Language, they can only use Lampung Language in a standard. From interviews that have been done, there is one child that use Lampung Language as his dominant language because he was already taught how to speak Lampung Language first before Indonesia Language and children that use mixed - language depends on the situation, especially in education and their environment. Because they do not usually practice Lampung Language in their home.

The home domain is the last bastion of a person's language maintenance (Istimurti, 2009: 351). Research on respondents who have children indicates that most of them deliberately do not inherit the Lampung Language to their children. The table below shows the language choice categories of parents and adult age when talking to children in the home field.

Table 3. Language choice with children (in the category of adult and children respondents)

\begin{tabular}{|c|c|c|c|c|c|c|c|c|c|}
\hline No. & Respondents' Age & Total & \% & LL & \% & IL & \% & ML & \% \\
\hline 1. & $21-40$ years old & 12 & 54,5 & 5 & 41,6 & 4 & 33,4 & 3 & 25 \\
\hline 2. & $>40 y e a r s$ old & 10 & 45,4 & 6 & 60 & 3 & 30 & 1 & 10 \\
\hline & Total & 22 & 100 & 11 & & 7 & & 4 & \\
\hline
\end{tabular}

From the table above, it shows that Lampung Language mostly used as a dominant language in Padang Cermin followed by Indonesia Language and Mixed Language. The writer interviewed all adults that have been married and have children as the source. There is only one parent of 10 parents (10\%) who have chosen mixed language as their daily communication with their children, it is done because many of their family members still do not understand about Lampung Language. While 5 of 12 adults (54\%) purely interact with their children using Lampung Language same as 6 of 10 parents (60\%). In other words, Lampung Language has been used across two generations.

In the questionnaire, researchers also included questions about the language used by respondents to other family members, such as relatives and parents. Researchers found that the maintenance level of Lampung Language when talking to older or the peers tends to be high, but not to the younger ones. This indicates the occurrence of language shift because of the age of parents and adults who use more Indonesia Language when talking to children. Likewise, children who are much more dominant use Language Language to their parents.

\section{Factors that led to Language Shift}

\section{Social}

Based on the results of questionnaires and interviews that have been done, respondents admitted that the use of Indonesia Language which is done by children and teenagers more than Lampung Language due to social factors. Characteristics of a multilingual region make them use Indonesia Language as a bridge to interact with people from other tribes. Padang Cermin area is located in the urban area that has heterogeneous community characteristics, so the use of Indonesia Language makes it easier for them to communicate. Outdoor activities which is experienced by some teenagers respondents also make the level of the maintenance of Lampung Language decreased.

\section{Economy Development}

According to the interview with some respondents and informants, a heterogeneous environment or those which is visited by many migrants make them unwilling to speak Indonesia Language to facilitate them in interacting, running a business and get a job. In the domain of work with different tribes, they use Indonesia Language and some use Mixed Language with regional languages. Thus, the economic development in the area inhabited by the spokesman affects their maintenance of Lampung Language level. 


\section{Educational Development}

The lack of strength in the maintenance of Lampung language can also be seen from the efforts of language and cultural heritage of their children. Based on the results of the study, it was found that teaching and learning activities in schools and interaction with inter-ethnic communities made the respondents reluctant to actively use Lampung Language in the family environment. The results showed that adult respondents when talking to children more dominant use Indonesia Language.

The results of the interviews with the respondents showed that the school greatly influenced their language choice. The respondents who have had children, speak Indonesia Language on the grounds that their children understand the lessons at school. They are aware that education is an escalator for worthy welfare, so children are directed to use Indonesia Language at home and outside the home in order to smooth out their education.

\section{Language Attitude}

The researchers also find out how the attitude of language among people who speak Lampung Language. The respondents were asked about several issues related to language attitudes. This is meant to find out whether there is a significant relationship between language attitudes and the level of language maintenance or not. Apparently, in all age categories, their language attitudes tend to be positive. This can be seen in the table below:

Statements:

A. Lampung language must be inherited as an ancestral heritage

$B$. Lampung language is important to use

C. Lampung language is a buffer of culture

D. Lampung Language as a sign of identity

E. Lampung language shows intimacy

F. Glad to be invited to speak the language of Lampung outside the village

G. Proudly mastering the language of Lampung

H. It is necessary to improve the Lampung Language in the domain of family

I. Lampung language needs to be taught in school

$J$. The government needs to campaign the language of Lampung

\begin{tabular}{|c|c|c|c|c|c|}
\hline No & Statements & N & Mean & SD & Note \\
\hline 1 & A & 30 & 4,54 & 0,50 & High \\
\hline 2 & B & 30 & 3,97 & 0,71 & Medium \\
\hline 3 & C & 30 & 4,1 & 0,75 & High \\
\hline 4 & D & 30 & 2,86 & 0,68 & Low \\
\hline 5 & E & 30 & 4,23 & 0,67 & High \\
\hline 6 & F & 30 & 4,06 & 0,63 & High \\
\hline 7 & G & 30 & 4,5 & 0,50 & High \\
\hline 8 & H & 30 & 3,96 & 0,71 & Medium \\
\hline 9 & I & 30 & 4,13 & 0,73 & High \\
\hline 10 & J & 30 & 3,06 & 0,70 & Low \\
\hline
\end{tabular}

From the table above, it can be concluded that the attitude of adults respondents towards language attitude tend to be positive. Meanwhile the highest percentage goes to statements number one that is Lampung Language should be kept and inherited for the next generation. This high percentage indicates their acknowledgment of the existence of the Lampung language as a tool of cultural inheritance. If one's mind is already negative to the Lampung language, it could be that everything done related to its preservation will be considered as useless. Perception as a high culture will have an impact on behavioral aspects.

On the other hands, it appears that the majority have a positive attitude towards the Lampung language. Both adult and teenager respondents are generally proud of the language of Lampung. They believe in the Lampung language as the identity and buffer of culture, as the language of intimacy, and they also feel happy if they are invited to speak outside the village. In general, the results indicate positive attitudes of the respondents to the other case with adult respondents, the number children respondents who answered "neutral" when they are asked whether they are proud or not in mastering the Lampung language, and happy or not to speak Lampung language quite significant. In fact, the pride of language (language parole) in the younger generation can encourage the development and revitalization of language. 
Some of adult respondents are eager to teach their children the language of Lampung. The rest, that answered not willing because of the importance of education and in order to communicate with the surrounding community. However, when the adults and teenagers respondents were asked about the government's efforts to report the language of Lampung, $8 \%$ answered agree, and 6\% disagreed. Similarly, on the question of efforts to improve the language of Lampung in the domain of school and education, as much as $3 \%$ answered disagree. However, there is a tendency that a small percentage of young respondents will be apathetic to the effort of preservation of Lampung language.

\section{Conclusion}

From the analysis that has been done, the researcher formulated some conclusions that answer the problem and prove the hypothesis. Firstly, the maintenance of Lampung Language in Padang Cermin District depends on whom they are talking to, what topics which is being talked about, and the circumstances that lie behind them and also the situation when they are getting upset and angry consciously and unconsciously. The maintenance of Lampung language towards adult respondents is still strong because they apply it in the domain of home, religion, transaction, and education. While for children or teenagers respondents tend to use Indonesia Language when they are in the domain of education and social aspect. Thus, it is clear that the older the age of a person, the stronger the level of language maintenance. Conversely, to the younger generation is vice versa.

Secondly, it appears that there has been a shift in language from the oldster respondents in Padang Cermin population using Lampung Language to adult, children, and adolescents. The factors that led to language shift are; First, the social factor that allows the inhabitants of the Padang Cermin society to interact with the urban people who have heterogeneous characteristics; Secondly, the economic factor, which allows Padang Cermin society to use the Indonesian language to make it easier to run a business and get a job; Third, the educational factors that make parents reluctant to teach Lampung language to their children, or the dominant Indonesian language use in school so that children do not use the Lampung Language actively.

Thirdly, the language attitude influences the level of Lampung Language maintenance in Padang Cermin district. Respondents of both oldster and adult have positive language attitudes with strong language maintenance rates. However, in young respondents, it was found that positive language attitudes did not mean that the level of language maintenance is strong. Thus, the relationship of language maintenance with language attitudes, especially to young respondents, is interesting to be analyzed

\section{References}

Agustina, Eka Sofia. 2004. Penerapan Pendekatan Kontekstual dalam Pembelajaran Kosakata Bahasa Lampung. Bandung: Universitas Pendidikan Indonesia.

Chaer, Abdul and Leonie Agustina. 2004. Sosiolinguistik Perkenalan Awal (Edisi Revisi). Bandung: Rineka Cipta.

Chaer, Abdul. 2002. Kajian Bahasa (Struktur Internal, Pemakaian, dan Pemelajaran). Bandung: Rineka Cipta.

Edwards, V. John. 2008. "Foundations of Bilingualism". The Handbook of Bilingualism, Bhatia K. Tej, et al. (ed.). Chicester: Wiley-Blackwell

Fasold, Ralp. 1987. The Sociolinguictis of Society. New York: Basil Blackwell Ltd

Hadikusuma, Hilman.1983. Bahasa Lampung. Lampung: Gunung Pesagi.

Wardhaugh, Ronald \& Fuller Janet. M. 2015. An Introduction to Socilonguistics $7^{\text {th }}$ ed. Malden: Blackwell Publishing. 